\title{
Pandemic Challenges for the Technological Startups in the Russian Regions
}

\author{
Stepan Zemtsov \\ Director ${ }^{\mathrm{a}}$, spzemtsov@gmail.com \\ Alexander Chepurenko \\ Professor ${ }^{\mathrm{b}}$, achepurenko@hse.ru \\ Alexander Mikhailov \\ Research Fellowa, mikhaylov-aa@ranepa.ru

\begin{abstract}
${ }^{a}$ Center for Economic Geography and Regional Studies, The Russian Presidential Academy of National Economy and Public Administration (RANEPA), 82 bld. 1, Vernadsky ave., Moscow 119571, Russian Federation
\end{abstract} \\ ${ }^{\mathrm{b}}$ Department of Sociology, National Research University Higher School of Economics (NRU HSE), 20, Myasnitskaya str., Moscow \\ 101000, Russian Federation
}

\begin{abstract}
$\mathrm{T}$ echnological startups help to adapt economies to the global risks and allow one to track future trends. This paper identifies the main trends and birth factors of new high-tech companies in the Russian regions during 2013-2020. In 2020, fewer than 10,000 startups were created, this number has been steadily declining (by $40 \%$ since $2015)$, especially during the pandemic $(-21 \%)$. Most of the startups are concentrated in Moscow, the Moscow region, St Petersburg, and the largest metropolitan areas. The share of the Leningrad, Belgorod, Kaliningrad, Lipetsk, Ulyanovsk, and Kaluga regions is growing due to the proactive policies of local authorities. Most startups are associated with knowledge-intensive services for business (B2B) and digital technologies. In 2020, their number increased in pharmaceuticals (about 100\%) and in the production of medical devices (by about 30\%).

Based on the results of econometric analysis, start-up activity in Russia, analogous to countries with an established market economy, depends upon human capital concentration, market access, and a favorable business climate.

Universities, through attracting students, especially those in STEM specialties, stimulate startup creation; although the share of university startups does not exceed one third of a percent. Budgetary and university expenditures on $R \& D$ are ineffective in terms of creating new companies. The influence of development institutions on start-up activity was not found, while clusters and technology parks have a weak effect. The growth of startups is lower in regions with a predominance of large organizations, as well as in resource centers. The latter may be one of the manifestations of the "resource curse". Startup activity is stable over time and depends on the situation in neighboring regions, which limits the chances to change the situation by means of entrepreneurship support policy. During the pandemic, start-up activity decreased minimally in regions with large metropolitan areas and a high level of education. Recommendations include tools for establishing a more balanced cross-regional situation by implementing the model of an entrepreneurial university, an expansion of start-ups' access to capital and markets, and the regionalization of entrepreneurship policies.
\end{abstract}

Keywords: high-tech sector; entrepreneurship; regional entrepreneurial ecosystem; Russia; entrepreneurial universities; development institutions; STEM; clusters; pandemic; COVID-19

Citation: Zemtsov S., Chepurenko A., Mikhailov A. (2021) Pandemic Challenges for the Technological Startups in the Russian Regions. Foresight and STI Governance, 15(4), 61-77. DOI: $10.17323 / 2500-2597.2021 .4 .61 .77$ 


\section{Introduction}

Technological entrepreneurship is one of the key factors of socio-economic development [Audretsch, Keilbach, 2008; Ries, 2011]. Young firms account for about $20 \%$ of employment [OECD, 2020] and almost half of new jobs, while in the United States they provide up to $50 \%$ of productivity growth. The acceleration of the technological revolution, among other things due to the effect of the COVID-19 pandemic, increases the risks of structural unemployment and inequality [Zemtsov, 2020], which can be effectively countered by supporting and simplifying conditions for the creation of new firms, especially in promising high-tech industries [Fossen, Sorgner, 2021].

The 2020 corona-crisis was a stress test for entrepreneurs around the world. According to the TEA (Total Early-Stage Entrepreneurial Activity) index, in 21 out of 35 surveyed countries the share of people starting or maintaining a new business decreased (Figure 2). In Russia, this share decreased from $9.3 \%$ to $8.5 \%$ due to reduced household incomes, the closure of foreign markets, and epidemiological lockdowns [Kudrin et al., 2021; Mau et al., 2020]. Even before the pandemic, Russia lagged behind many other post-Soviet countries in this regard [Zbirovsky, 2017], despite the improvement in formal conditions for doing business [Zemtsov, 2020] and the expansion of the toolset applied to support entrepreneurship [Semenova et al., 2019a]. The new venture birth rate remains below the level of the business closures [Obraztsova, Chepurenko, 2020], while the number of new high-tech companies has been decreasing since 2016 [Barinova et al., 2020]. The pandemic shock only exacerbated this trend.

In $2020,72 \%$ of the world's young high-tech companies experienced a decrease in revenue; the number of new ventures' market entries fell compared to the 2019 level $^{1}$ and their total amount was below the 2018 level. $^{2}$ At the same time, reduced software prices combined with the businesses' forced transition to the internet gave rise to a new wave of start-ups specializing in digital and financial technologies, telemedicine services, and online education [Kuckertz et al., 2020; Dahlke et al., 2021; Fossen, Soergner, 2021]. This demonstrates that the pandemic is transforming the venture industry structure and that of the future economy.

Start-ups transform ideas into new technologies and products [Audretsch, Lehman, 2005]. In the Russian regions where the density of small businesses is $1 \%$ higher, GRP per capita is $0.22 \%-0.67 \%$ higher than in others [Zemtsov, 2020] and the innovation system is more efficient as well. At the same time, even with a high share of research and development $(R \& D)$ personnel and a rich scientific heritage, high-tech solutions are rarely commercialized [Auzan et al., 2019], a situation called the "Russian innovation paradox"
[Gokhberg, Kuznetsova, 2012]. One explanation is the generally low entrepreneurial activity despite the fact that conditions for creating and fostering start-ups in different regions vary.

Identifying barriers to and incentives for the development of start-ups in Russian regions could contribute to a better understanding of territorial and industryspecific challenges and trends, and help in developing measures to support new ventures in the post-pandemic period. The main objective of the paper is to identify the trends and factors in the creation of new high-tech companies in Russian regions in 2013-2020. Such an empirically based study is new in Russia.

\section{Review of High-Technology Start-Up Studies}

Despite its wide usage, there is still no generally accepted definition of the term "start-up". Typically, it refers to a recently (less than one year ago) established firm largely controlled by its founders, which presents new products or services to the market and owns intellectual property rights to the $\mathrm{m}^{3}$ [Robehmed, 2013]. About $70 \%$ of such companies are closed within 10 years of their establishment due to the lack of customers, funding, team members, or competitor actions.

The founders' personal traits and specialized skills [Stuetzer et al., 2013] or the availability of entrepreneurial capital [Erikson, 2002] are the internal factors in start-up growth. External ones are associated with the overall socioeconomic context or the entrepreneurial ecosystem [Isenberg, 2011; Mason, Brown, 2014; Audretsch, Belitski, 2017; Chepurenko, 2019; Zemtsov et al., 2020]. It largely determines demand and supply for new businesses [Verheul et al., 2002]. If the former depends on people's and businesses' incomes and interest in new products and services (new markets), the latter is determined by the characteristics of human capital as well as structural and institutional conditions (Figure 1).

As for the regional context (Table 1), many researchers support the idea that the concentration of human capital and research potential play a fundamental role in start-up creation [Lasch et al., 2010; Qian et al., 2012]. More than $95 \%$ of start-up founders had higher education and recruited appropriately qualified teams [Wright et al., 2007]. It is no coincidence that universities, research centers, and $\mathrm{R} \& \mathrm{D}$ divisions of large companies that employ and train highly qualified professionals often turn into start-up "generators" [Guerrero et al., 2016; Fritsch, Wyrwich, 2019]. About 44\% of the world's start-ups (Figure 2) are concentrated in California and Massachusetts, the leading entrepreneurial ecosystems which originally emerged around MIT and Stanford University [Saxenian, 1996]. By 2017, the

\footnotetext{
https://startupgenome.com/article/state-of-the-global-startup-economy, accessed 19.08.2021.

https://www.crunchbase.com/, accessed 19.08.2021.

${ }^{3}$ https://www.forbes.com/advisor/investing/what-is-a-startup, accessed 19.08.2021.
} 


\section{Figure 1. Regional Technological Entrepreneurship Model}

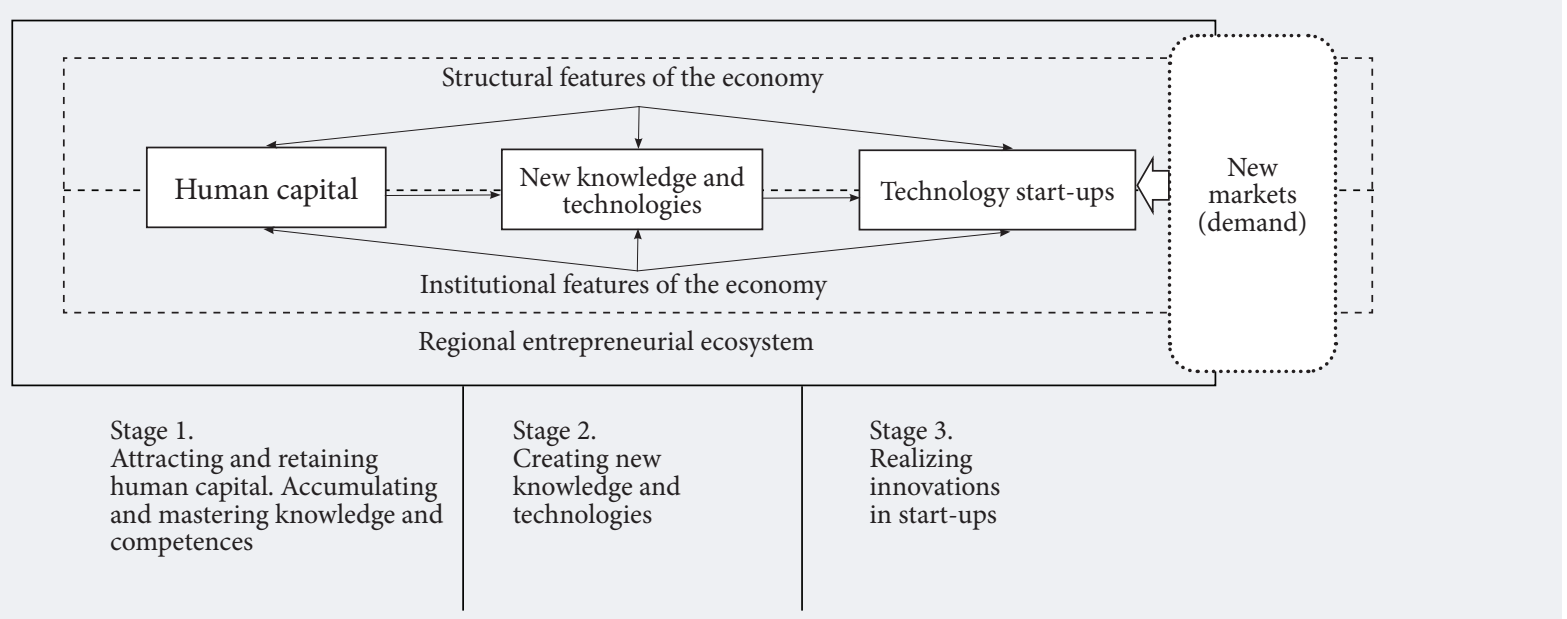

Source: authors, based on [Verheul et al., 2002; Isenberg, 2011; Qian et al., 2012].

latter's alumni had launched more than 50 unicorn $^{4}$ companies (out of approximately 270 in the world, or $\approx 19 \%$ ).

The innovation cycle concept allows one to build a technological entrepreneurship model (Figure 1) comprising three stages, each consistent with specific university functions (or missions) [Zemtsov et al., 2015]. At the first stage, universities attract the best minds, creative people, professionals, and future entrepreneurs in the region, accumulate knowledge and competencies, and educate workers. At the second stage, new knowledge is created in the form of academic publications and patents, as a potential resource for establishing new companies. At the last stage, leading universities support start-ups and provide appropriate infrastructure.

A significant amount of time is required for technological entrepreneurship to become embedded in the university and the regional community, accumulate skills and knowledge for building cooperation networks, and foster a favorable socio-cultural environment and business climate [Shirokova et al., 2018]. Such embeddedness increases the persistence of entrepreneurial ecosystems so that leading and outsider regions in terms of start-up activity remain unchanged for decades and even hundreds of years [Fritsch, Wyrwich, 2018; Zemtsov, 2020]. That is why the rate of new technology companies' creation in the region directly depends upon the presence of old, established universities there [Fritsch, Wyrwich, 2018].

The institutional context largely determines both the decision to become an entrepreneur [Lee et al., 2003; Aparicio et al., 2016; Eriksson, Rataj, 2019] and the perception of risks and opportunities associated with this decision. From a formal point of view, new ventures are interested in the firm registration requirements, the availability of external funding, the regulatory environment, and the intellectual property regime. As to the informal aspects, the most important ones include corruption, mistrust between people, paternalism, and differences in values which adversely affect technological projects involving a large number of parties [Auzan et al., 2019; Zemtsov, 2020].

The structure of the economy affects both the supply of and demand for start-ups. For example, extracting industries demonstrate relatively weak demand for new technologies and, accordingly, for start-ups. The number of the latter, as shown in [Fritsch, Wyrwich, 2018] on the basis of German data, is historically lower in the localities close to coal mining regions, due to the "resource curse" [Guriev, Sonin, 2008; Lyubimov, 2016] which pushes the local capital and labor into the more profitable resource sector. Dependence upon resource rents leads to the disruption of local institutions and corruption, eliminating incentives to launch new ventures for technology entrepreneurs. Unlike large natural resource producers (who are typically not keen to see new competition), start-up activity tends to be higher in major, diversified metropolitan areas due to the high concentration of players, strong competition between them, the scale and diversity of markets, etc. [Beaudry, Schiffauerova, 2009; Audretsch, Fritsch, 1994]. Clusters emerging in regions specializing in high-tech industries [Delgado et al., 2010; Belitski, Desai, 2015] provide access for entrepreneurs to appropriate infrastructure, and knowledge spillovers from large companies and universities into start-ups emerges.

A high density of start-ups in one region increases their density in the neighboring ones due to the interregion- 
Table 1. Summary of Previously Identified StartUp Activity Factors at Regional Level

\begin{tabular}{|c|c|c|c|c|c|c|c|c|}
\hline Literature & 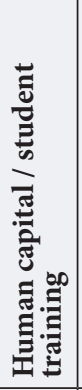 & 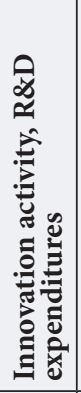 & 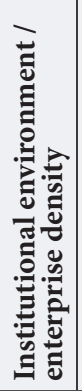 & 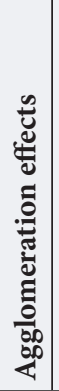 & 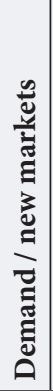 & 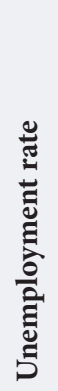 & 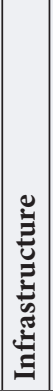 & 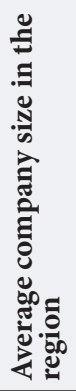 \\
\hline $\begin{array}{l}\text { [Audretsch, Fritsch, } \\
1994]\end{array}$ & + & & & + & + & $\diamond$ & & $\diamond$ \\
\hline [Lee et al., 2003] & + & + & + & + & + & - & & - \\
\hline $\begin{array}{l}\text { [Audretsch, } \\
\text { Lehman, 2005] }\end{array}$ & + & + & & & & & & \\
\hline $\begin{array}{l}\text { [Fritsch, Mueller, } \\
\text { 2007] }\end{array}$ & & + & + & $\diamond$ & + & - & & \\
\hline $\begin{array}{l}{[\text { [Audretsch, }} \\
\text { Keilbach, 2008] }\end{array}$ & & + & & + & + & - & & \\
\hline [Plummer, 2010] & & + & & + & + & & & - \\
\hline [Lasch et al., 2011] & + & + & + & + & & $\diamond$ & & \\
\hline [Qian et al., 2012] & + & - & - & $\diamond$ & & & & \\
\hline $\begin{array}{l}\text { [Fritsch, Aamoucke, } \\
\text { 2013] }\end{array}$ & + & + & + & & & $\diamond$ & & \\
\hline $\begin{array}{l}\text { [Audretsch, Belitski, } \\
\text { 2017] }\end{array}$ & & & + & & $\diamond$ & & + & \\
\hline $\begin{array}{l}{[\text { Belitski, Desai, }} \\
\text { 2015] }\end{array}$ & + & + & + & & & & $\diamond$ & \\
\hline $\begin{array}{l}\text { [Goel, Saunoris, } \\
\text { 2017] }\end{array}$ & $\diamond$ & + & + & + & + & & & \\
\hline [Sun et al., 2017] & & + & + & $\diamond$ & $\diamond$ & & & \\
\hline $\begin{array}{l}\text { [Fritsch, Wyrwich, } \\
\text { 2018] }\end{array}$ & + & & & + & & & & \\
\hline $\begin{array}{l}\text { [Fritsch, Wyrwich, } \\
\text { 2019] }\end{array}$ & + & & & + & & & & \\
\hline $\begin{array}{l}\text { [Eriksson, Rataj, } \\
\text { 2019] }\end{array}$ & + & & + & - & & - & & \\
\hline \multicolumn{9}{|c|}{$\begin{array}{l}+- \text { positive effect; }-- \text { adverse effect; } \diamond-\text { ambiguous. } \\
\text { Source: authors. }\end{array}$} \\
\hline
\end{tabular}

al knowledge spillovers and skilled labor, the emergence of value chains, and other positive results [Plummer, 2010; Zemtsov, 2020]. Entrepreneurship support policy tools play an important role in these processes [Smallbone, Welter, 2020; Zemtsov et al., 2020] since they help the authorities to reduce transaction costs by improving the business environment, removing barriers, and upgrading the infrastructure. Direct financial support can be more effective in combination with private capital [Cumming et al., 2017].

\section{Start-Ups in the Russian Regions during the Pandemic Period}

The pandemic has affected small businesses in the Russian regions in different ways. A representative survey of small businesses conducted by the Public Opinion
Foundation in March 2021 revealed the following picture in the country's federal districts (Figures 2-5).

One can see significant differences between the disadvantaged situation of small and medium-sized enterprises (SMEs) in the Volga region, the South, and Central Russia on the one hand, and the relatively better situation in Siberia and the North Caucasus Federal District, on the other. The latter have a relatively small number of SMEs per 10,000 residents with the predominance of low profit margin micro-businesses and the population's high self-sufficiency in basic products and services. In contrast with the federal districts with more developed small entrepreneurship, the low initial base seems to be affecting the comparisons in this case.

Rising costs are often the reason for a decline in profits. SMEs' situation in the Volga region was, as expected, worse than the average for the whole sample, while in the North Caucasus it was more favorable. The difficult situation in Siberia requires a specific explanation.

The impact of direct restrictions turned out to be much less adverse in the federal districts with a lower population density (Siberia, the Far East), where, in contrast to the more densely populated areas, the restrictive measures were introduced selectively.

Finally, personnel shortages have most severely affected SMEs in the North Caucasus and turned out to be less of a problem in the Southern Federal District and Siberia. Due to the geographical and economic characteristics of the latter regions, it is easier to attract cheap labor there, while small businesses in construction, retail, and other industries where profit margins depend on the availability of labor are less developed.

Russia lags behind the world's leading economies (Figure 6) in terms of entrepreneurial activity expressed as the TEA index and the concentration of technology companies, ranking only $22^{\text {nd }}$ by their total number and $35^{\text {th }}$ by their per capita number. In Moscow and St. Petersburg, the latter indicator scores are higher than the national average (six and two times, respectively), but still much lower than in the leading global cities. For example, Boston's value (which rounds up the top ten) is 4.5 times higher than Moscow's. Moscow's global ranking by the amount of venture deals and the number of business angels is even lower [Boos et al., 2020]. Russia's low involvement in entrepreneurship reduces the potential number of start-ups.

The overall business dynamics in Russia can hardly be described as favorable. Since 2016, the company birth rate (the number of newly created firms per 1,000 existing ones) remains below the death rate. In general, in 2020 the number of new companies in Russia decreased by $23.4 \%$, but the number of registered private high-tech enterprises only fell by $16.8 \%$, i.e., start-ups (private firms with the OKVED codes for mediumand high-technology industries or knowledge-intensive services (Table 2) [Barinova et al., 2020]) turned out to be more resistant to the pandemic's impact than business as a whole. After some growth in 2019, 


\section{Figure 2. Decrease in Business Profitability by} Federal District (share of mentions, \%)

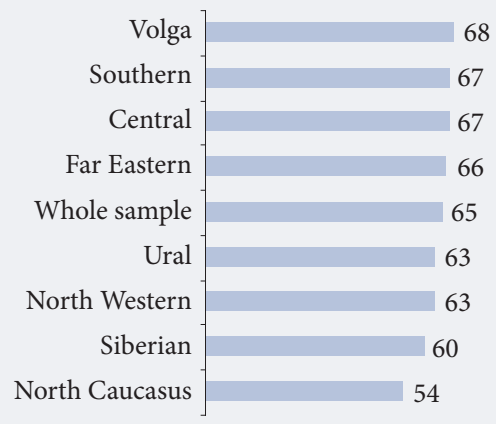

Source: authors, based on data collected in the scope of the project "Small business in (post)pandemic reality" (TR-145) of the HSE Basic Research Centre, 2021.

the number of start-ups producing finished products (i.e., those with revenues) decreased by $21.5 \%$ in 2020 . About a third of start-ups have non-zero revenues, $73 \%$ of them made a profit, and only $133(0.44 \%)$ owned intangible assets including intellectual activity results. Only half of start-ups established in 2015 and a third of those created in 2010 continued operations in 2021 (Figure 7). Among start-ups with non-zero revenues, the relevant figure was much higher at $65 \%$.

As for start-ups' sectoral structure (Table 2, Figure 4), in 2020 about $46 \%$ of them provided knowledge-intensive business services (KIBS), such as legal, accounting, recruiting, management, and others. A fifth of the newly created firms (and about $15 \%$ of the revenue of new ventures) belonged in the information and communication technology (ICT) sector. Together, KIBS and ICT, along with chemistry and pharmaceuti-

\section{Figure 4. Direct Restrictions on Economic Activities by Federal District (share of mentions, \%)}

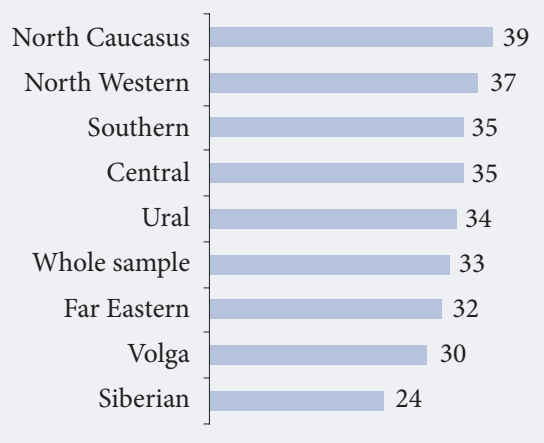

Source: authors, based on data collected in the scope of the project "Small business in (post)pandemic reality" (TR-145) of the HSE Basic Research Centre, 2021.
Figure 3. Increased Expenditures and Problems with Current Payments by Federal District (share of mentions, \%)

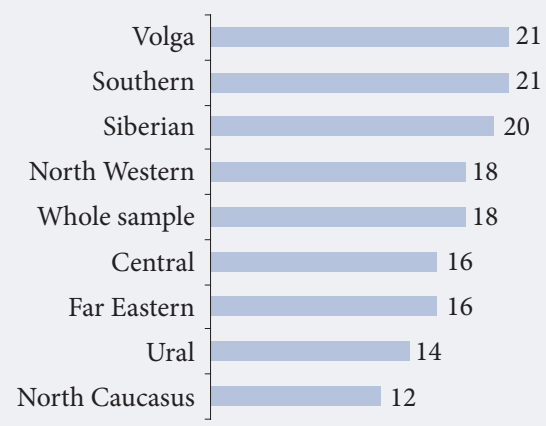

Source: authors, based on data collected in the scope of the project "Small business in (post)pandemic reality" (TR-145) of the HSE Basic Research Centre, 2021.

cals, grew faster than other sectors in 2020. In pharmaceuticals, the number of start-ups has doubled, in the production of medical instruments, it grew 1.3 times, while the production of vehicles, veterinary sciences, and aerospace transportation have significantly strengthened their positions. New ventures operating in these industries and in $R \& D$ have significantly increased revenues. Services related to restructuring business processes, digitization and automation, research, and medicine were in high demand during the pandemic. The success of transportation start-ups can be explained by the demand for unmanned vehicles, but it was more likely caused by the fragmentation of companies and the change of the OKVED codes to receive public support. The entire manufacturing sector accounts for less than 19\% of technology start-ups, though their share in the high-tech sector's revenues exceeds 45\% [Barinova et al., 2020].

\section{Figure 5. Personnel Shortages by Federal District (share of mentions, \%)}

Source: authors, based on data collected in the scope of the project "Small business in (post)pandemic reality" (TR-145) of the HSE Basic Research Centre, 2021. 


\section{Figure 6. Start-up Activity by Country}

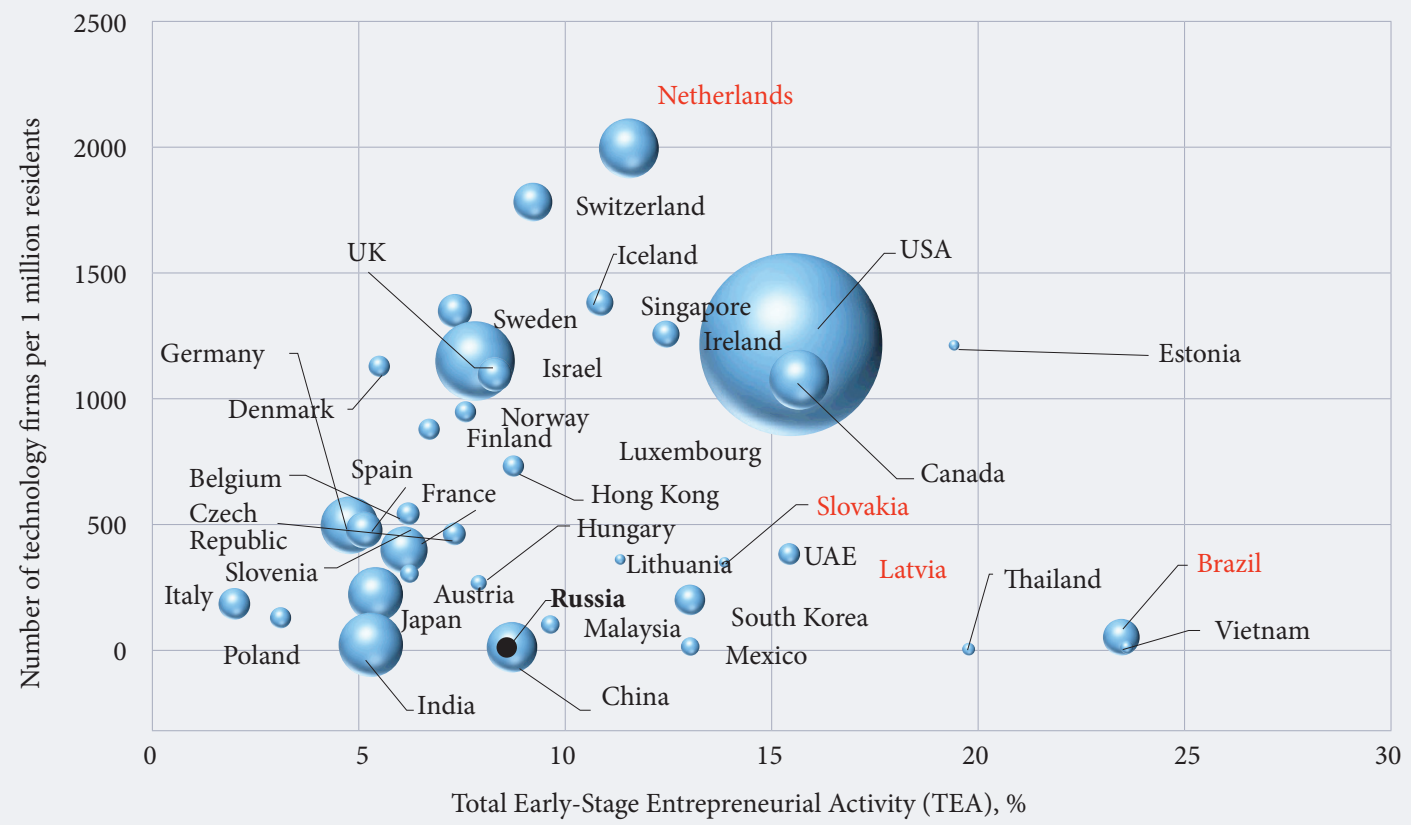

Note: countries whose TEA values increased in 2020 are underlined.

Sources: start-up data (as of March 2021): Crunchbase (https://www.crunchbase.com/discover/organisation.companies/a4f7810fb97b1b0d98f 9b645146bf455, accessed on 18.06.2021); population data: World Bank, 2021 (https://data.worldbank.org/, accessed on 18.06.2021); TEA data: Global Entrepreneurship Monitor (GEM), 2021. (https://www.gemconsortium.org/, accessed on 18.06.2021).

\section{Figure 7. Number of Existing and New High-tech Firms in 2015-2020 in Russia (as of September 2021)}

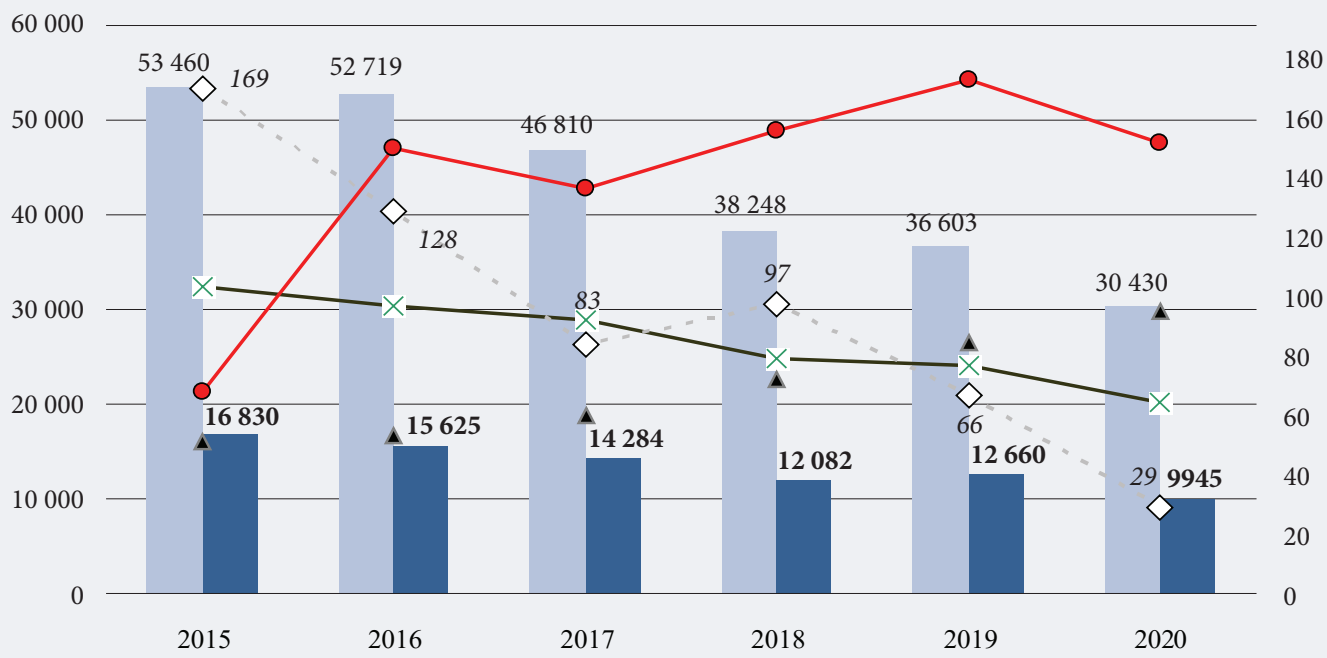

Number of new private high-technology firms, units

Number of new private high-technology firms with non-zero revenue, units

- $\times$ - Companies' birth rate per 1,000 companies (right axis)

- Companies death rate per 1,000 companies (right axis)

$\diamond-$ Number of small innovative enterprises affiliated with universities (right axis)

A Share of operating companies in the number of high-tech start-ups created in the specified year, $\%$

Sources: data on creation and liquidation of companies: Rosstat (https://rosstat.gov.ru/folder/14036/, accessed on 18.06.2021); of hightech of companies: SPARK (https://www.spark-interfax.ru/, accessed on 18.06.2021); RUSLANA (https://ruslana.bvdep.com, accessed on 18.06.2021); of business societies: Accounting and monitoring of SIEs (https://mip.extech.ru/index.php, accessed on 18.06.2021). 
To some extent, start-ups' industry distribution may reflect forthcoming changes in the structure of the economy, though the share of the high-tech sector in GDP currently does not exceed $24.3 \%$ (21.8\% in 2019). Significant changes have occurred here over the past 20 years: in 2000, KIBS accounted for only $35 \%$ of start-ups (in $202046 \%$ ), ICT for $14.7 \%$ (21\%), and the manufacturing sector for $25.7 \%$ (19\%).

On average, about 1.3 start-ups are created for every 10,000 able-bodied Russian residents; in 2000 this figure was 0.9 and in 2013 it was 2.3. The technology-driven start-ups in Russia are highly heterogeneous geographically. Approximately every fourth such company is created in Moscow, which together with St. Petersburg already account for about $40 \%$ of these firms. The top ten regions (including Tatarstan, the Sverdlovsk, Novosibirsk, Samara, Nizhniy Novgorod, and Krasnodar regions, and Bashkortostan) account for approximately $62 \%$ of start-ups (about $54 \%$ in 2013 ) and $42 \%$ of the workforce. The rate of start-up creation (Figure 9) is higher in large metropolitan areas where major educational and research centers, industries with high added value, and a service economy are concentrated [Barinova et al., 2020], and in coastal haven zones where a variety of services to support foreign economic activity are provided (the Kaliningrad, Leningrad, Primorsky, and Krasnodar regions). The start-up density is lower in the North Caucasus (due to the specifics of the local institutional environment) and in the northern mining areas which do not have the necessary infrastructure, large universities, or a technological specialization. The distribution of start-up activity by region is quite stable: the correlation coefficient between the 2020 and 2000 values is 0.78 , which exceeds the average for all small businesses (0.65). In 2020, the number of startups grew in only 14 regions (16\%), which can be most often explained by the previous year's low base effect (less than 50 companies). The Leningrad and Kaliningrad regions, in contrast to the general background with much higher scores, pursue consistent policies to support technology start-ups in the immediate vicinity of large markets (the EU and St. Petersburg).

Some of the successful regional start-ups sooner or later migrate to major high-tech centers with the appropriate infrastructure and access to funding and development institutions' support. This outflow weakens the already low potential of most regions. Subsequently some start-ups, having grown and transitioned into large company status, move their head offices to other countries, among other reasons due to sanctions-related restrictions. For example, the global game developer Playrix was founded in the Vologda region, but now operates in Dublin.
The above trends are confirmed by a survey of 630 Russian technology entrepreneurs ${ }^{5}: 41 \%$ of them reside in Moscow and $72 \%$ of the start-ups they own are focused on providing services to businesses. Just over half (51\%) assessed the pandemic's impact as positive, especially for educational and financial projects in high demand. As to the barriers and challenges of 2020, the respondents mentioned reduced household incomes, the weakening of the ruble, and the closure of borders, i.e., the shrinking of available markets. At the same time, $70 \%$ of start-ups did not fire their employees or cut salaries, $51 \%$ even plan to hire new workers, and $74 \%$ have actually created new jobs. Thus, a high concentration of high-tech players in the region not only indicates the presence of favorable conditions for the development of a smart economy but can also partially alleviate the negative effects of the pandemic.

The majority of domestic universities are not focused on research- or entrepreneurship-related objectives [Zemtsov et al., 2015], so relevant ecosystems do not emerge around them. Special legislative steps were taken to facilitate the creation of small innovative enterprises (SIEs) in the form of university-owned business societies. ${ }^{6}$ However, legal restrictions on contracts and funding still remain in place, along with the risks of legal prosecution of entrepreneurs for the improper use of public funds. Many SIEs were established for reporting purposes rather than for actual business ones. The creation of SIEs peaked in 2011 at 376 and then gradually decreased to a low of 29 in 2020 . Among start-ups with non-zero revenues, their share decreased from $1 \%$ to $0.29 \%$. Though more than half of Russian students would like to set up a business within five years of graduation (the average for the world is 38\%) [Shirokova et al., 2016], most of them are not offered any entrepreneurship courses [Dukhon et al., 2018].

The Russian venture capital market almost doubled in 2020 thanks to foreign investors, but its share in GDP does not exceed $0.008 \%$ (the average for the OECD countries is $0.08 \%{ }^{7}$ ). Numerous development institutions responsible for funding venture projects are expected to give it an impetus [Semenova et al., 2019a], but the bulk of the funds allocated by the Skolkovo Foundation and the Russian Venture Company (RVC) goes toward Moscow-based companies, while these institutions' activities in Russian regions remain very low. About $21 \%$ of the surveyed entrepreneurs ${ }^{8}$ have any external investors, but only in $2 \%$ of these cases are these venture funds, while more than half of the respondents had no access to public support during the pandemic since their industry was not included on the list of adversely affected ones. More than $85 \%$ of the surveyed start-ups (Figure 7) have persistent debts.

\footnotetext{
${ }^{5}$ https://drive.google.com/file/d/1ecdEQJz4s0aAEORAl4v87HBo0e7tMb1_/view, accessed 19.08.2021.

RF Federal Law of 2 August 2009 No. 217-Ф3. https://rg.ru/2009/08/04/int-dok.html, accessed 19.08.2021.

https://stats.oecd.org/Index.aspx?DataSetCode=VC_INVEST\#, accessed 19.08.2021.

${ }^{8}$ https://drive.google.com/file/d/1ecdEQJz4s0aAEORAl4v87HBo0e7tMb1_/view, accessed 19.08.2021.
} 


\section{Figure 8. Structure of Non-Zero Revenue Start-Ups by Branch, 2020}

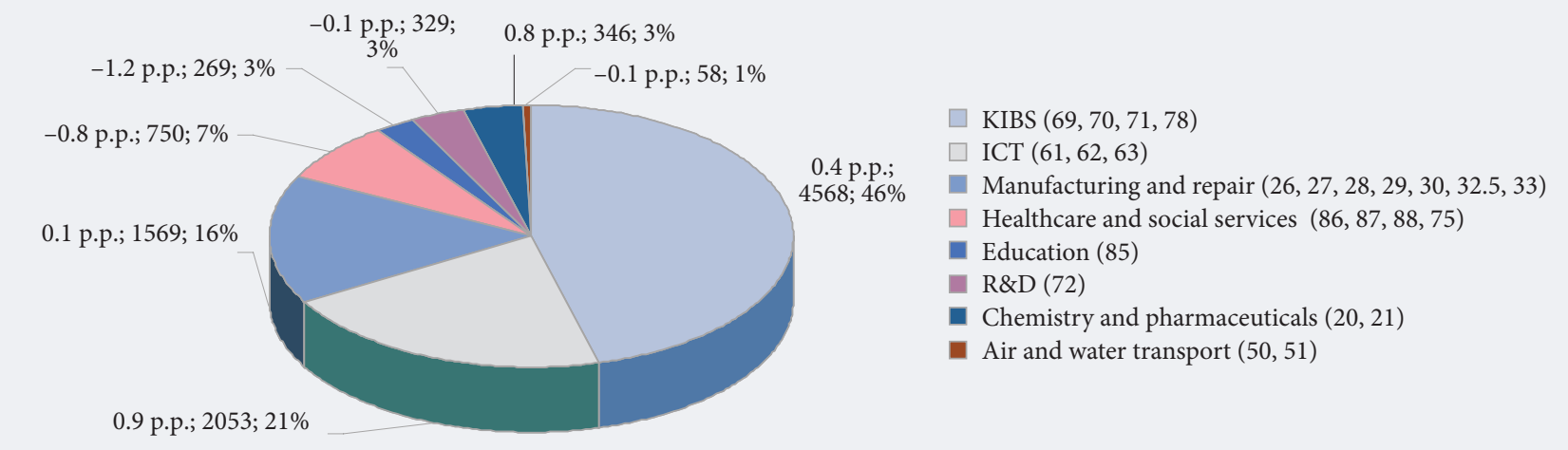

Note: OKVED codes are indicated in brackets; the first number in the captions indicates the growth of sector's share compared with 2019 (in percentage points), the second - the number of start-ups, and the third - the sector's start-ups' share in their total number.

Source: SPARK (https://www.spark-interfax.ru/, accessed on 18.06.2021).

The government made some steps to improve the conditions for start-ups in Russia during the pandemic. These measures, however, seem to lack a regional focus. In the absence of evident results, the feasibility of many of them requires evaluation.

\section{Methodology of the Study}

The key studies in the area under consideration (Table 1) were carried out on the basis of data for developed market economies. Therefore, without additional verification, they cannot be extrapolated to the Russian economy with its specific features such as the excessive share of state-owned enterprises, the low level of small entrepreneurship and private venture capital in most regions, the disproportionately high role of the extractive industries, and so on. In turn, sample surveys do not always adequately reflect overall processes, while the reproducibility of the previously obtained results and conclusions also requires verification.

The literature review and the trend analysis allow one to suggest the following hypotheses for empirical testing:

1. The accumulation of human capital, and especially of students, in the region [Wright et al., 2007] and R\&D expenditures [Qian et al., 2012] create conditions for the emergence of high-technology businesses. In developed economies, a larger emergence of start-ups is provided by universities with a higher share of STEM majors [Fritsch, Wyrvich, 2019; Perignat, Katz-Buonincontro, 2019]. With the growth of creative industries in recent years, art is increasingly considered a relevant training area as well (STEAM). These trends are of little relevance in Russia due to the specifics of the national educational system, the modest role of universities in $R \& D$ and in the creation of start-ups, and the low efficiency of the public R\&D sector.
2. A favorable business environment (investment climate, availability of capital) increases the likelihood of the emergence of technology start-ups [Audretsch, Belitski, 2017; Eriksson, Rataj, 2019]. The business climate in Russia is steadily improving [Zemtsov, 2020] due to, among other things, the Agency for Strategic Initiatives' (ASI) 9 efforts; however, in the case of technology start-ups, which require support from specific institutions, the effectiveness of these efforts remains questionable. The easier availability of bank capital may not have played a significant role because companies prefer to rely on their own resources. The government policy of replacing private venture funds with development institutions [Semenova et al., 2018] and its results need a separate evaluation.

3. To promote start-up development, regions need to build high-quality ICT and innovation infrastructure including access to digital resources and online markets [Audretsch, Belitski, 2017; Chepurenko et al., 2017]. Modern digital platforms provide access to global consumers, technologies, and labor markets. At the same time, across the entire venture industry, the impact of ICT may turn out to be less significant, along with the role of clusters and technology parks which have been actively developing in Russia in recent years [Barinova et al., 2020].

4. Regions with large markets, metropolitan areas, and high-income (and therefore high purchasing power) neighboring territories have higher demand for new products and services, which opens up market niches for start-ups [Audretsch, Fritsch, 1994; Lee et al., 2003; Fritsch, Mueller, 2007]. However, this demand may be significant for servicing small businesses and not make an appreciable impact specifically on IT start-ups.

5. The raw materials production-skewed structure of the economy hinders the development of the venture industry due to the low demand for new technologies

${ }^{9}$ https://asi.ru/government_officials/rating/, accessed 19.08.2021. 


\section{Figure 9. Regional Distribution of Start-ups in Russia in 2015-2020}

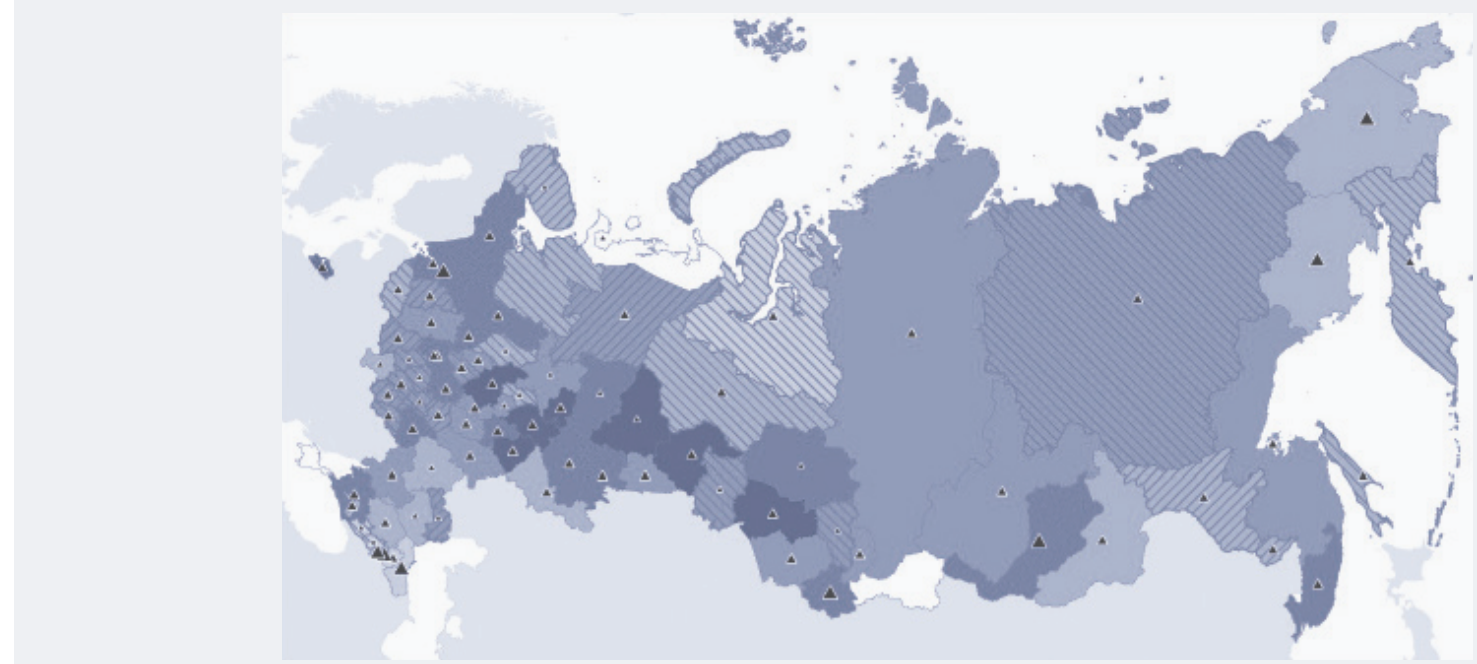

Number of new private high-technology firms with non-zero revenues per 10 thousand workforce in 2020

\begin{tabular}{|l|l|l|l|l|l|l|}
\hline No data & $<0.3$ & $0.3-0.7$ & $0.7-1.1$ & $1.1-1.5$ & $>1.5$
\end{tabular}

Number of new private high-technology firms with non-zero revenues in 2020 as share of 2015 value, \%

$$
\text { . }<50 \quad \text { \ } 50-100 \quad \Delta>100
$$

7/1 Number of firms under consideration grew in 2020

1V Number of firms under consideration decreased in 2020 by more than a third

Sources: SPARK (https://www.spark-interfax.ru/, accessed on 18.06.2021), Rosstat (https://rosstat.gov.ru/, accessed on 18.06.2021).

and other aspects of the "resource curse". An in-depth analysis of this relationship has not yet been carried out in the literature.

6. The smaller the average effective market size of a respective organization in the region, the higher the entry barriers into the local market (Table 1) and the lower the density of start-ups there [Lee et al., 2003; Plummer, 2010]. In Russia, the average organization size is largely determined by the number and role of public institutions, while the correlation with the number of start-ups needs to be checked.

7. The embeddedness of entrepreneurial and innovation activities in the region play a key role in the development of technological start-ups, i.e., the earlier a university was established there, the higher the likelihood of its innovation-related functions (and thus increasing the density of start-ups) [Fritsch, Wyrwich, 2018]. Most of the universities established during the Soviet period performed only educational functions, so their impact upon the processes under consideration needs to be confirmed.

8. High start-up activity in some territories promotes the emergence of new ventures in the neighboring ones [Plummer, 2010]. The validity of this statement for Russia, with its long distances and institutional barriers between different parts of the country, remains in question.
An econometric model was developed to test the above hypotheses in which the number and growth rate of non-zero revenue start-ups were used as dependent variables; the independent ones are described in Table 3. Each of the selected factors corresponding to the hypotheses included several variables.

To test the hypotheses, several types of models were built using the ordinary least squares method (OLS) with adjusting indicators' heteroscedasticity, random (RE) and fixed effects (FE). If the first two types allow one to identify a general pattern, the latter takes into account individual characteristics of regions.

\section{Econometric Assessment}

The models' empirical results are presented in Table 4 (only significant dependencies). In general, the suggested hypotheses can be considered confirmed.

Start-up activity is higher in regions with a larger share of people potentially possessing advanced competencies: the Tyumen and Yaroslavl regions, Bashkortostan, St. Petersburg, etc. For example, a 1\% increase in the average duration of employees' education (in years) leads to a $0.26-0.55 \%$ increase in start-up density, and to a $0.35 \%$ growth rate increase in start-up density (Models 1-4). This is one of two key factors in maintaining start-up activity during the pandemic 
(Model 8). Despite the interregional imbalance and the decline in the quality of education in the 2000 s, its role in technological development remains important (Model 3).

Despite the small number of innovative companies established in and by universities (Figure 3), the importance of student numbers for creating start-ups has been confirmed. An increase in their number in a region by $1 \%$ leads to a $0.5 \%$ increase in the number of start-ups there (Model 1), and to a $0.13 \%$ higher growth rate (Model 4 ). Though young entrepreneurs are rarely found among the founders of successful technology companies [Azoulay et al., 2020], proximity to high-ranking universities provides access to cutting-edge technology and highly skilled professionals, among other things due to the knowledge spillover effect. In regions with an appreciable share of university and college graduates specializing in STEM (such as the Tomsk, Rostov, and Samara regions, St. Petersburg, Tatarstan, etc.), start-up density is also higher, which confirms the effectiveness of relevant support measures and the relevance of restructuring the education system. The pandemic hindered inter-university mobility (which was already rather low in Russia) and reduced the opportunities for live communication necessary for the formation of business teams, so the variables in Model 8 have insignificant values.

R\&D expenditures (which traditionally remain under $1 \%$ of GDP) do not directly affect start-up activity, since about $64.4 \%$ of them are made in the public sector which is very inefficient in creating new companies. However, if the share of the entrepreneurial sector in the regional R\&D expenditures increases by $1 \%$, the density and growth rate of the number of startups increase by $0.1-0.13 \%$ and $0.07 \%$, respectively. In private laboratories focused on obtaining end results, knowledge spillover effects lead to the emergence of new companies through intrapreneurship, the expanded network of branches, launching spin-offs, etc. A classic example is one of the world's best business ecosystems in Boulder, Colorado (US), with the major IBM research center [Mason, Brown, 2013]. In Russia, a similar example is the AvtoVAZ Science and Technology Centre (in Togliatti), which has nurtured numerous engineering start-up founders. The high share of universities in R\&D expenditures (such as in Mari $\mathrm{El}$, the Kostroma region, Chechnya, Altai, etc.) on the contrary reduces the likelihood of the emergence of and increase in the number of start-ups, since university $R \& D$ in most of the regions remain poorly developed and only achieve progress in cooperation with businesses, and then only linked with strong research centers. The recent major federal programs to promote the excellence (" $5-100$ ", federal and flagship universities) have little changed this situation.

Start-up density in the regions is higher the more developed the banking sector there is (Models 4-6), i.e., there is the more available funding (Moscow, St. Petersburg, the Kaliningrad, Voronezh, and Novosibirsk regions), since most new ventures with non-zero revenues borrow funds to develop and launch new products or services on the market. In Model 5, the increase in the number of start-ups was positively correlated with the investment climate in the region (the SIA rating), including local authorities' policies. This confirms the relevance of government efforts to improve the business climate, but does not prove the sustainability of the achieved effect.

The correlation between the intensity of the new ventures' emergence in the regions and indicators of entrepreneurship support provided by the development institutions turned out to be insignificant in all models, i.e., it has not been confirmed. Most of the new companies outside the capitals did not have access to such support, either because of low awareness or doubts or fears regarding dealing with the public authorities [Zemtsov, 2020]. Also, the bulk of financial resources were managed by RUSNANO and the Industry Development Fund, which were not focused on supporting start-ups. This is partly why, at the beginning of 2021, the Russian government initiated a reform of the development institutions.

A $1 \%$ increase in household income leads to an increase in the number of start-ups by $0.16 \%$ (Model 3), mainly those serving large local businesses and private households. Start-ups are more likely to emerge in or near large and rapidly growing cities (Model 7) where new market niches appear and opportunities for cooperation and knowledge spillovers open up [Lee et al., 2003; Audretsch, Keilbach, 2008; Plummer, 2010; Goel, Saunoris, 2017]. In major metropolitan areas the availability of internet access and the demand for online services are higher, so city size remained the second most important factor in maintaining start-up activity in 2020 (Model 8). Digitization has become one of the survival conditions for businesses during the pandemic [Kudrin et al., 2021], giving an impetus to the development of the internet sector [Fossen, Soergner, 2021]. It also played a key role in the emergence of start-ups previously (Model 2).

Only one of the models confirmed the (rather modest) contribution of clusters and technology parks to start-up industry development (Model 6). Technology parks' effect is limited to regions adjacent to large markets and those with extensive bank networks, such as, e.g., the Kaluga and Leningrad regions. However, most often technology parks remain empty or perform office functions.

The average organization size has the strongest adverse effect upon start-up activity among regional economies' structural features (Models 1-7), which can be an indirect sign of high market entry barriers due to the predominance of large players. Such organizations, including public sector ones (and "natural monopolies"), are common in regions with a high value of this indicator (Chechnya, Kabardino-Balkaria, Dagestan, Yamalo-Nenets Autonomous Region, the Zabaikalsky, Astrakhan, and Kemerovo regions). During the pan- 


\section{Table 2. Non-Zero Revenue Start-Ups' Characteristics in 2020/2019}

\begin{tabular}{|c|c|c|c|c|c|c|c|}
\hline Code & Activity (industry) & $\begin{array}{l}\text { Number } \\
\text { in } 2020\end{array}$ & $\underset{\%}{\text { Share, }}$ & $\begin{array}{l}\text { Revenue } \\
\text { in } 2020, \\
\text { mln. rub. }\end{array}$ & $\underset{\%}{\text { Share, }}$ & $\begin{array}{c}\text { Growth in } \\
\text { number in } \\
2020 / 2019, \%\end{array}$ & $\begin{array}{l}\text { Growth in } \\
\text { revenues in } \\
2020 / 2019, \%\end{array}$ \\
\hline \multicolumn{8}{|c|}{ High-technology activities } \\
\hline 21 & Production of drugs and medical materials & 49 & 0.5 & 1847.7 & 1.4 & 222.7 & 1677.4 \\
\hline 26 & $\begin{array}{l}\text { Production of computers, electronic and optical } \\
\text { products }\end{array}$ & 105 & 1.1 & 3043.1 & 2.2 & 70.5 & 64.7 \\
\hline 30.3 & $\begin{array}{l}\text { Production of aircrafts, and spacecrafts, and } \\
\text { equipment }\end{array}$ & 1 & 0.0 & 6.6 & 0.0 & 33.3 & 47.5 \\
\hline \multicolumn{8}{|c|}{ Medium-technology activities } \\
\hline 20 & Production of chemicals and chemical products & 297 & 3.0 & 5098.5 & 3.7 & 94.6 & 180.9 \\
\hline 27 & Production of electrical equipment & 205 & 2.1 & 2951.9 & 2.2 & 76.8 & 46.5 \\
\hline 28 & $\begin{array}{l}\text { Production of machinery and equipment not } \\
\text { included in other categories }\end{array}$ & 417 & 4.2 & 5055.2 & 3.7 & 86.5 & 66.2 \\
\hline 29 & $\begin{array}{l}\text { Production of motor vehicles, trailers and semi- } \\
\text { trailers }\end{array}$ & 56 & 0.6 & 735.3 & 0.5 & 60.9 & 39.7 \\
\hline 30 & $\begin{array}{l}\text { Production of other vehicles and equipment, } \\
\text { excluding } 30.3\end{array}$ & 60 & 0.6 & 2942.9 & 2.2 & 125.0 & 438.1 \\
\hline 32.5 & $\begin{array}{l}\text { Production of medical instruments and } \\
\text { equipment }\end{array}$ & 45 & 0.5 & 777.2 & 0.6 & 128.6 & 693.3 \\
\hline 33 & $\begin{array}{l}\text { Repair and installation of machinery and } \\
\text { equipment }\end{array}$ & 680 & 6.8 & 7747.9 & 5.7 & 74.9 & 60.6 \\
\hline \multicolumn{8}{|c|}{ Knowledge-intensive activities } \\
\hline 50 & Water transport activities & 33 & 0.3 & 2267.8 & 1.7 & 52.4 & 100.5 \\
\hline 51 & Air and space transport activities & 25 & 0.3 & 486.0 & 0.4 & 113.6 & 179.4 \\
\hline 61 & Activities in the field of telecommunications & 134 & 1.3 & 1048.7 & 0.8 & 78.8 & 95.0 \\
\hline 62 & $\begin{array}{l}\text { Computer software development and related } \\
\text { services }\end{array}$ & 1390 & 14.0 & 16919.3 & 12.4 & 82.8 & 63.4 \\
\hline 63 & Information technology activities & 529 & 5.3 & 3566.7 & 2.6 & 81.0 & 35.6 \\
\hline 69 & Activities in the field of law and accounting & 1823 & 18.3 & 8218.8 & 6.0 & 78.1 & 54.7 \\
\hline 70 & Head office activities; management consulting & 648 & 6.5 & 41922.7 & 30.8 & 74.1 & 498.3 \\
\hline 71 & $\begin{array}{l}\text { Activities in the field of architecture and } \\
\text { engineering }\end{array}$ & 1868 & 18.8 & 20162.3 & 14.8 & 82.9 & 83.5 \\
\hline 72 & Research and development & 329 & 3.3 & 5487.9 & 4.0 & 76.3 & 172.5 \\
\hline 75 & Veterinary activities & 58 & 0.6 & 133.8 & 0.1 & 118.4 & 95.8 \\
\hline 78 & Employment and recruiting activities & 229 & 2.3 & 2306.9 & 1.7 & 74.1 & 11.5 \\
\hline 85 & Education & 269 & 2.7 & 1150.0 & 0.8 & 53.8 & 35.0 \\
\hline 86 & Healthcare activities & 568 & 5.7 & 2056.4 & 1.5 & 69.6 & 24.6 \\
\hline 87 & Residential care activities & 31 & 0.3 & 60.8 & 0.0 & 100.0 & 98.7 \\
\hline \multirow[t]{2}{*}{88} & Non-residential care activities & 93 & 0.9 & 187 & 0.1 & 59.2 & 78.6 \\
\hline & Total for high-technology sector & 9945 & 100 & 136181 & 100 & 78.5 & 84.9 \\
\hline
\end{tabular}

demic this factor did not play an appreciable role because the crisis affected all regions.

An increased overall share of the high-tech sector contributes to the emergence of start-ups (Models 1 and 7), while a high share of extraction industries in GRP determines low start-up rates. The reasons may include such negative aspects of a resource-based economy as the lack of fostering ecosystems (most large extraction companies conduct $\mathrm{R} \& \mathrm{D}$ at their head offices, i.e., in the
Russian capital) and priority is given to less risky and more profitable investments in resource production.

The importance of temporal and spatial effects of entrepreneurial activity is confirmed, which are rarely given attention in the literature and taken into account when making political decisions. First, as regards the time that the first university was founded in the region: the earlier it happened (St. Petersburg, Moscow, Tatarstan, the Tver and Tomsk regions), the higher the density 
Table 3. Factors and Variables Applied in the Models

\begin{tabular}{|c|c|c|c|}
\hline $\begin{array}{l}\text { Factor and designa- } \\
\text { tion }\end{array}$ & Variable & Source & Period \\
\hline \multirow{3}{*}{$\begin{array}{l}\text { Human capital }(h u- \\
\text { mancap) }\end{array}$} & Average number of years of workers' education, units & Calculations & 2010-2019 \\
\hline & Number of students per 1,000 population, people & Rosstat & 2010-2019 \\
\hline & Share of university and college graduates specialising in STEM, \%* & Calculations & $2015-2017$ \\
\hline \multirow[t]{3}{*}{ S\&T potential $(r n d t)$} & Share of internal R\&D expenditures in GRP, \% & Rosstat & $2010-2019$ \\
\hline & Share of the commercial sector in R\&D expenditures, $\%$ & Calculations & 2010-2019 \\
\hline & Share of universities in R\&D expenditures, \% & Rosstat & 2012-2019 \\
\hline \multirow{3}{*}{$\begin{array}{l}\text { Institutional environ- } \\
\text { ment, business climate } \\
\text { (inst) }\end{array}$} & SIA Investment Climate Index, points & SIA & $2014-2018$ \\
\hline & Aggregate index of banking services' availability in the region, points & Bank of Russia & 2010-2019 \\
\hline & $\begin{array}{l}\text { Amount of public financial support for start-ups provided by development } \\
\text { institutions per } 10 \text { thousand workforce }\end{array}$ & $\begin{array}{l}{\left[\begin{array}{l}\text { Semenova } \\
\text { 2019] }\end{array}\right.} \\
\end{array}$ & $2010-2017$ \\
\hline \multirow[t]{2}{*}{ Infrastructure (infr) } & $\begin{array}{l}\text { Share of organisations with internet access with at least } 2 \text { Mbps bandwidth } \\
\text { in the total number of organisations, } \%\end{array}$ & Rosstat & $2010-2020$ \\
\hline & $\begin{array}{l}\text { Number of cluster members and technology park residents per 1,000 work- } \\
\text { ers, units }\end{array}$ & $\begin{array}{l}{[\text { Barionova et al., }} \\
2020]\end{array}$ & $2016-2018$ \\
\hline \multirow{4}{*}{$\begin{array}{l}\text { Market potential and } \\
\text { agglomeration effects } \\
\text { (market) }\end{array}$} & Monthly per capita income minus minimum living costs, roubles & Rosstat's calculations & $2010-2020$ \\
\hline & $\begin{array}{l}\text { Total monetary income of the entire population minus minimum living } \\
\text { costs, billion roubles }\end{array}$ & Rosstat's calculations & $2010-2020$ \\
\hline & $\begin{array}{l}\text { Market potential (GRP of this and other regions, and countries' GDPs di- } \\
\text { vided by the distance to them), trillion roubles }\end{array}$ & Calculations & $2010-2020$ \\
\hline & Regional capital's population, $\%$ & Rosstat & $2010-2020$ \\
\hline \multirow{3}{*}{$\begin{array}{l}\text { Structure of economy } \\
\text { (economstructure) }\end{array}$} & \multirow{3}{*}{$\begin{array}{l}\text { Average organisation size (ratio of the number of employees to the number } \\
\text { of organisations), people }\end{array}$} & Rosstat & 2010-2019 \\
\hline & & Rosstat & 2010-2019 \\
\hline & & Rosstat's calculations & $2010-2020$ \\
\hline Confidence & Age of the oldest university, years & Calculations & $2010-2020$ \\
\hline $\begin{array}{l}\text { Interregional knowl- } \\
\text { edge spillovers }\end{array}$ & Average number of start-ups per workforce in neighbouring regions & Calculations & 2013-2020 \\
\hline \multicolumn{4}{|c|}{$\begin{array}{l}\text { *For more about the methodology see [Semenova et al., 2019b], and https://i-regions.org/reiting/monitoring-razvitiya-steam-ritm-obrazovaniya-v- } \\
\text { regionakh-airr/, accessed on 18.06.2021. }\end{array}$} \\
\hline
\end{tabular}

and growth in the number of start-ups (Models 1-2, 4-6) due to embeddedness. Second, a high density of start-ups in neighboring territories increases their density and growth rate in the region under consideration (Models 2-4).

\section{Conclusions and Recommendations}

The pandemic not only became a challenge, but opened a window of opportunity for entrepreneurs, especially technology start-ups, offering new, customized products and services [Doern et al., 2019; Davidsson, 2020] and those focused on developing and building up their businesses [Eggers, 2020]. Enterprises emerging after natural disasters and catastrophes, not burdened by the technological and organizational inertia of the pre-crisis period and therefore showing a better performance after it ends, tend to adapt to new circumstances better than others do [Williams, Shepherd, 2016]. The number of start-ups in Russia, however, remains very modest: in three-quarters of the country's regions fewer than 100 of such firms are created annually (Figure 5). For most regions, fostering new high-tech companies seems to be both an important and difficult objective to achieve.
Though most start-ups are consistently concentrated in Moscow, the Moscow region, St. Petersburg, and major metropolitan areas, in recent years the shares of the Leningrad, Belgorod, Kaliningrad, Lipetsk, Ulyanovsk, and Kaluga regions have been growing due to proactive local policies. This allowed the above regions to become leaders in the SIA investment attractiveness ratings which reflect the authorities' efforts to support small businesses: simplifying procedures, promoting industrial parks, and so on. Start-up structure is shifting toward providing knowledge-intensive services (distant learning, telemedicine, fin-tech, etc.) and high-tech manufacturing (robots, unmanned vehicles, medical devices, etc.). The correlation coefficient between regional start-up activity in 2020 and 2000 is about 0.67 , and for the number of start-ups in various industries, this figure is 0.85 . The identified spatial and sectoral trends seem to be quite stable and are likely to persist after the pandemic ends.

The factors of start-up activity in the Russian regions described above on the whole match the global patterns: the importance of accumulating human capital, developing the commercial R\&D sector, proximity to large markets, favorable business climate, and adequate infrastructure. At the same time, no evidence was dis- 


\section{Table 4. Factors affecting technology start-up density and growth of their number in Russian regions in 2013-2020}

\begin{tabular}{|c|c|c|c|c|c|c|c|c|c|}
\hline & \multirow{2}{*}{$\begin{array}{l}\text { Dependent variable } \\
\text { Evaluation method }\end{array}$} & \multicolumn{3}{|c|}{$\begin{array}{l}\text { Number of new privately } \\
\text { owned high-technology firms } \\
\text { with non-zero revenues per } \\
10000 \text { able-bodied people }\end{array}$} & \multicolumn{4}{|c|}{$\begin{array}{c}\text { Dependent variable growth, \% } \\
\text { (year to year) }\end{array}$} & \multirow{2}{*}{$\begin{array}{c}\begin{array}{c}\text { Ratio of } \\
\text { dependent } \\
\text { variable values in } \\
2020 \text { to } 2019, \%\end{array} \\
\text { OLS } \\
\end{array}$} \\
\hline & & RE & RE & FE & RE & RE & RE & FE & \\
\hline \multirow[t]{2}{*}{ Factor group } & Factors & 1 & 2 & 3 & 4 & 5 & 6 & 7 & 8 \\
\hline & Constant & $\begin{array}{l}-0.11 \\
(0.65)\end{array}$ & $0.14(0.93)$ & $\begin{array}{l}-2.2^{* * *} \\
(0.62)\end{array}$ & $\begin{array}{l}-0.31 \\
(0.42)\end{array}$ & $\begin{array}{c}-3.8^{* * *} \\
(1.36)\end{array}$ & $\begin{array}{l}1.02^{* * *} \\
(0.22)\end{array}$ & $\begin{array}{l}2.14^{* * *} \\
(0.75)\end{array}$ & $-1.64(2.48)$ \\
\hline \multirow[t]{3}{*}{$\begin{array}{l}\text { Human } \\
\text { capital }\end{array}$} & $\begin{array}{l}\text { Average number of } \\
\text { years in education }\end{array}$ & $\begin{array}{l}0.26^{\star} \\
(0.14)\end{array}$ & $\begin{array}{l}0.55^{\star \star \star} \\
(0.16)\end{array}$ & $\begin{array}{l}0.35^{\star} \\
(0.18)\end{array}$ & $\begin{array}{l}0.35^{\star *} \\
(0.15)\end{array}$ & & & & $1.95^{\star *}(0.89)$ \\
\hline & $\begin{array}{l}\text { Number of students per } \\
100 \text { people }\end{array}$ & $\begin{array}{l}0.52^{* * *} \\
(0.09)\end{array}$ & & & $\begin{array}{l}0.13^{\star *} \\
(0.05)\end{array}$ & & & & \\
\hline & \begin{tabular}{|l|} 
Share of university \\
and college graduates \\
specialising in STEM, \%
\end{tabular} & & $\begin{array}{l}0.29^{* *} \\
(0.11)\end{array}$ & & & & & & \\
\hline \multirow[t]{2}{*}{ S\&T potential } & $\begin{array}{l}\text { Share of the commercial } \\
\text { sector in R\&D } \\
\text { expenditures, \% }\end{array}$ & $\begin{array}{l}0.1^{\star *} \\
(0.05)\end{array}$ & $\begin{array}{l}0.13^{\star * *} \\
(0.05)\end{array}$ & & $\begin{array}{l}0.07^{* *} \\
(0.03)\end{array}$ & & & & \\
\hline & $\begin{array}{l}\text { Share of universities in } \\
\text { R\&D expenditures, } \%\end{array}$ & $\begin{array}{l}-0.05^{*} \\
(0.02)\end{array}$ & $\begin{array}{c}-0.06^{* *} \\
(0.03)\end{array}$ & & $\begin{array}{c}-0.03^{* *} \\
(0.01)\end{array}$ & & & & \\
\hline \multirow{2}{*}{$\begin{array}{l}\text { Institutional } \\
\text { conditions } \\
\text { (including } \\
\text { political) }\end{array}$} & $\begin{array}{l}\text { Banking Services } \\
\text { Availability index }\end{array}$ & & & & $\begin{array}{l}0.43^{\star * *} \\
(0.08)\end{array}$ & $\begin{array}{l}0.43^{* * *} \\
(0.15)\end{array}$ & $\begin{array}{l}0.25^{* * *} \\
(0.06)\end{array}$ & & \\
\hline & $\begin{array}{l}\text { SIA Investment Climate } \\
\text { Index }\end{array}$ & & & & & $\begin{array}{l}0.8^{* * *} \\
(0.22)\end{array}$ & & & \\
\hline \multirow[t]{2}{*}{ Infrastructure } & $\begin{array}{l}\text { Share of organisations } \\
\text { with broadband } \\
\text { internet access, \% }\end{array}$ & & $\begin{array}{l}0.19^{*} \\
(0.09)\end{array}$ & & & & & & \\
\hline & $\begin{array}{l}\text { Per capita number } \\
\text { of cluster members } \\
\text { and technology park } \\
\text { residents }\end{array}$ & & & & & & $\begin{array}{l}0.02^{*} \\
(0.01)\end{array}$ & & \\
\hline \multirow{4}{*}{$\begin{array}{l}\text { Market } \\
\text { niches and } \\
\text { metropolitan } \\
\text { area effect }\end{array}$} & $\begin{array}{l}\text { Total monetary income } \\
\text { minus minimum living } \\
\text { costs }\end{array}$ & & & $\begin{array}{l}0.16^{*} \\
(0.8)\end{array}$ & & & & & \\
\hline & $\begin{array}{l}\text { Number of residents in } \\
\text { the regional capital city, } \\
\text { people }\end{array}$ & & & & & & & & $0.09^{\star * \star}(0.03)$ \\
\hline & $\begin{array}{l}\text { Growth of the number } \\
\text { of residents in the } \\
\text { regional capital city, \% }\end{array}$ & & & & & & & $\begin{array}{l}6.3^{* *} \\
(2.82)\end{array}$ & \\
\hline & $\begin{array}{l}\text { Growth of regional } \\
\text { market potential, } \%\end{array}$ & & & & $\begin{array}{l}0.3^{* * *} \\
(0.05)\end{array}$ & $\begin{array}{l}0.42^{\star * \star} \\
(0.06)\end{array}$ & $\begin{array}{c}0.22^{\star * *} \\
(0.05)\end{array}$ & $\begin{array}{l}0.23^{* * *} \\
(0.07)\end{array}$ & \\
\hline \multirow{4}{*}{$\begin{array}{l}\text { Structural } \\
\text { specifics of the } \\
\text { economy }\end{array}$} & $\begin{array}{l}\text { Average organisation } \\
\text { size }\end{array}$ & $\begin{array}{c}-1.02^{* * *} \\
(0.18) \\
\end{array}$ & $\begin{array}{c}-1.17^{\star * *} \\
(0.15) \\
\end{array}$ & $\begin{array}{l}-0.42^{* *} \\
(0.17)\end{array}$ & $\begin{array}{c}-0.47^{* * *} \\
(0.09)\end{array}$ & $\begin{array}{c}-0.46^{* * *} \\
(0.09) \\
\end{array}$ & $\begin{array}{c}-0.41^{\star * *} \\
(0.07) \\
\end{array}$ & $\begin{array}{l}-0.7^{* * *} \\
(0.25)\end{array}$ & \\
\hline & $\begin{array}{l}\text { Share of the high- } \\
\text { technology sector in } \\
\text { GRP, \% }\end{array}$ & $\begin{array}{c}0.22^{\star *} \\
(0.1)\end{array}$ & & & & & & & \\
\hline & $\begin{array}{l}\text { Increase in the share of } \\
\text { high-technology sector } \\
\text { in GRP, \% }\end{array}$ & & & & & & & $\begin{array}{l}0.29^{\star *} \\
(0.12)\end{array}$ & \\
\hline & \begin{tabular}{|l|} 
Share of extractive \\
industries in GRP, \%
\end{tabular} & & & & & & & $\begin{array}{l}-0.04^{*} \\
(0.02)\end{array}$ & \\
\hline $\begin{array}{c}\text { Entrepre- } \\
\text { neurship roots }\end{array}$ & $\begin{array}{l}\text { Age of the oldest } \\
\text { university, years }\end{array}$ & $\begin{array}{l}0.22^{\star * \star} \\
(0.1)\end{array}$ & $\begin{array}{l}0.26^{\star * \star} \\
(0.09)\end{array}$ & & $\begin{array}{l}0.09^{\star *} \\
(0.03)\end{array}$ & $\begin{array}{l}0.19^{* * *} \\
(0.05)\end{array}$ & $\begin{array}{l}0.07^{\star} \\
(0.04)\end{array}$ & & \\
\hline $\begin{array}{c}\text { Interregional } \\
\text { knowledge } \\
\text { flow }\end{array}$ & $\begin{array}{l}\text { Average ratio of start- } \\
\text { ups to workforce in } \\
\text { neighbouring regions }\end{array}$ & & $\begin{array}{l}0.12^{\star * *} \\
(0.04)\end{array}$ & $\begin{array}{l}1.13^{* * *} \\
(0.11)\end{array}$ & $\begin{array}{c}0.08^{* * *} \\
(0.03)\end{array}$ & & & & \\
\hline Basic level & $\begin{array}{l}\text { Ratio of start-ups to } \\
\text { economically active } \\
\text { population a year } \\
\text { earlier }\end{array}$ & & & & $\begin{array}{l}-0.59^{* * *} \\
(0.09)\end{array}$ & $\begin{array}{c}-0.58^{* * *} \\
(0.08)\end{array}$ & $\begin{array}{c}-0.41^{\star * *} \\
(0.06)\end{array}$ & $\begin{array}{l}-1^{\star * *} \\
(0.1)\end{array}$ & $-0.29^{\star \star}(0.11)$ \\
\hline Adjusted $\mathrm{R}^{2}$ & & & & & & & & & 0.16 \\
\hline LSVD R $^{2}$ & & & & 0.9 & & & & 0.61 & \\
\hline
\end{tabular}


covered in Russia of the positive role played by university $R \& D$, publicly funded research, and development institutions, while the effect of clusters and technology parks is weak. However, the extractive sector suppresses start-up activity and the spatial and temporal effects limit the potential of entrepreneurship policies. The negative development trend of start-up activity factors does not allow for expecting appreciable progress in this area. Households' incomes and accessible markets are shrinking, the share of R\&D conducted by the commercial sector shows practically no growth, investments in universities do not pay back because the number of university start-ups stagnates - and all this despite the improvement in the formal conditions for doing business in many regions and the post-crisis acceleration in digitization. Therefore, let us try to outline a range of measures that could help overcome the above trends.

\section{Implementing the "Entrepreneurial University" Concept}

To adapt to new risks and opportunities, many Russian regions first of all need to retain their human capital, i.e., reduce the outflow of potential entrepreneurs to Moscow and abroad, and support their initiatives. This requires the following solutions:

- providing grant financing for regional entrepreneurial universities in the framework of the Strategic Academic Leadership Programme ${ }^{10}$ to teach students relevant skills [Chepurenko, 2017; Dukhon et al., 2018] and build start-up infrastructure. The pandemic experience suggests that projects to develop platforms and applications (to serve as a basis for start-ups offering solutions for the commercialization of relevant approaches) primarily need such support, along with services such as remote diagnostics, care for the sick and the elderly, artificial intelligence (AI), and so on in regional universities and academic institutions with strong medical and technological competences. "Adequate infrastructure facilities" mean production laboratories (fablabs) to make pilot products;

- increasing the share of graduates specializing in STEAM professions, which involves introducing innovative courses at the junction of engineering and creative disciplines using advanced ICT, establishing higher engineering schools, holding all kinds of technological competitions, developing new educational programs in regional universities that have adequate human and intellectual resources;

- promoting partnerships between technology companies and universities by introducing tax incentives and other preferential terms (e.g., selling them unused production facilities and other infrastructure at symbolic prices) when establishing basic university departments and engineering and prototyping centers at regional universities. Development institutions can also provide financial support for projects;

- supporting the collaboration of leading Russian universities with regional research centers: setting up "mirror laboratories" of leading Moscow universities (MIPT, MISIS, HSE, etc.) in local higher education institutions, organizing internships for their young scientists at leading entrepreneurial universities in Moscow and St. Petersburg.

The federal program Priority $2030^{11}$ and the projects "Technological Entrepreneurship Platform" and "Higher Engineering Schools" which involve the application of the above tools deserve special mention.

\section{Promoting Demand for Regional Start-ups' Products and Increasing Their Access to Potential Markets through the Application of Digital Technologies}

New challenges require expanding digital infrastructure and involving individuals and businesses in the digital economy. A specific program to support digitization and robotization of state-owned companies operating in many Russian regions could contribute to the emergence of new local markets for start-ups. Building and upgrading ICT infrastructure should be the priority in developing the digital environment in Russian regions, including broadband internet and $5 \mathrm{G}$ networks to promote the emergence of new industries in the framework of gignomics: 3D printing, augmented and virtual reality technologies, telemedicine, etc. Public-private partnerships and long-term debt instruments based on private investment are efficient formats for funding such projects in the regions [Cumming et al., 2017].

\section{Policies Promoting Regional Entrepreneurship Ecosystems and Bridging Interregional Gaps in the Start-up Activity}

The pandemic created the need to regionalize policies [Obraztsova, Chepurenko, 2020]. It is no coincidence that many responsibilities in the sanitation and epidemiology sphere and for providing support for the affected were delegated from the federal to regional authorities. However, the issue of introducing appropriate tax incentives remains unresolved.

Education, science and technology, entrepreneurial, and regional policies need to be coordinated on the basis of an ecosystem approach: inclusivity principles ("rules for all"), interconnectedness, consistency ("think small first"), openness, locality, and priority

\footnotetext{
${ }^{10} \mathrm{https} / / /$ www.minobrnauki.gov.ru/press-center/news/?ELEMENT_ID=21471, accessed 19.08.2021

${ }^{11}$ https://priority2030.ru/, accessed 19.08.2021.
} 
[Zemtsov et al., 2020]. Bridging interregional gaps in the levels of start-up activity and R\&D also requires further effort.

The weaknesses of most of the regional entrepreneurial ecosystems can be partially overcome by moving project offices with broad federal- and regional-level powers to personnel- and resource-deficient regions (similar to the INO Tomsk project). Industrial parks specializing in fine-tuning and promoting innovative solutions in the field of logistics (in the Far East), new materials (Ural), selection and organic foods (South), new transport technologies (North), AI (central Russia), and others can be established in federal districts with the participation of federal development institutions, leading universities, interregional business associations, representatives of the private venture capital industry, and NGOs. Currently many development institutions do not even have regional offices and focus exclusively on Moscow and Saint Petersburg [Semenova et al., 2019a], while R\&D conducted by Russian universities, despite their wide disciplinary coverage, typically do not take into consideration the specifics of the local economy and its strong sides.
Replicating best regional practices in attracting young entrepreneurs can be another area for making promotional efforts. For example, the Republic of Tatarstan is implementing a special rate mortgage and housing rental program for start-up founders willing to move in from other Russian regions ${ }^{12}$ or neighboring countries. Unlike social policy, initiatives to support technology start-ups cannot be equalizing and uniform ("one size fits all"). Co-financing start-ups in mining and agricultural regions will be less effective than in centers of research and education activities.

Applying the above new entrepreneurial policies to start-ups will increase the productivity of the innovation sector and that of the Russian economy as a whole.

This study was carried out in the framework of the state assignment for RANEPA in 2020 and on the basis of data collected over the course of the project "Small business in (post) pandemic reality" (TR-145) of the HSE Centre of Fundamental Research. The authors would like to thank Zarina Nurieva for her help in data collection and calculations and Maxim Belitsky, Yulia Tsareva, Alexander Pilyasov, and Daniil Kovalchuk for their valuable comments.

\section{References}

Aparicio S., Urbano D., Audretsch D. (2016) Institutional factors, opportunity entrepreneurship and economic growth: Panel data evidence. Technological Forecasting and Social Change, 102, 45-61. https://doi.org/10.1016/j.techfore.2015.04.006

Audretsch D.B., Belitski M. (2017) Entrepreneurial ecosystems in cities: Establishing the framework conditions. The Journal of Technology Transfer, 42(5), 1030-1051. https://doi.org/10.1007/s10961-016-9473-8

Audretsch D.B., Fritsch M. (1994) The geography of firm births in Germany. Regional Studies, 28(4), 359-365. https://doi.org $/ 10.1080 / 00343409412331348326$

Audretsch D.B., Keilbach M. (2008) Resolving the knowledge paradox: Knowledge-spillover entrepreneurship and economic growth. Research Policy, 37(10), 1697-1705. https://doi.org/10.1016/j.respol.2008.08.008

Audretsch D.B., Lehmann E.E. (2005) Does the knowledge spillover theory of entrepreneurship hold for regions? Research Policy, 34(8), 1191-1202. https://doi.org/10.1016/j.respol.2005.03.012

Auzan A.A., Komissarov A.G., Bakhtigaraeva A.I. (2019) Socio-cultural limitations of the commercialisation of innovations in Russia. Economic Policy, 14(4), 76-95. DOI: 10.18288/1994-5124-2019-4-76-95 (in Russ.)

Barinova V.A., Zemtsov S.P., Zinov V.G., Kidyaeva V.M., Krasnoselskikh A.N., Kurakova N.G., Semenova R.I., Fedotov I.V., Halimova S.R., Khafisov R.R., Tsareva Yu.V. (2020) National report "High-tech business in the Russian regions", Moscow, RANEPA, AIRR (in Russ.)

Beaudry C., Schiffauerova A. (2009) Who's right, Marshall or Jacobs? The localisation versus urbanisation debate. Research Policy, 38(2), 318-337. https://doi.org/10.1016/j.respol.2008.11.010

Belitski M., Desai S. (2016) What drives ICT clustering in European cities? The Journal of Technology Transfer, 41(3), 430-450. https://doi.org/10.1007/s10961-015-9422-y

Boos V.O., Gokhberg L.M., Islankina E.A., Ismagulova S.G., Kutsenko E.S., Streltsova E.A., Tyurchev K.S. (2020) Rating of innovative attractiveness of world cities, Moscow: NRU HSE (in Russ.).

Chepurenko A., Popovskaya E.V., Obraztsova O. (2017) Cross-regional Variations in the Motivation of Early-Stage Entrepreneurial Activity in Russia: Determining Factors. In: Entrepreneurship in Transition Economies (eds. A. Sauka, A. Chepurenko), Heidelberg, Dordrecht, London, New York: Springer, pp. 315-342. DOI:10.1007/978-3-319-57342-7_18

Chepurenko A.Yu. (2017) How and why to teach entrepreneurship to students: Polemical notes. Educational Studies Moscow, 3, 250-276. DOI: 10.17323/1814-9545-2017-3-250-276 (in Russ.).

Cumming D.J., Grilli L., Murtinu S. (2017) Governmental and independent venture capital investments in Europe: A firmlevel performance analysis. Journal of Corporate Finance, 42, 439-459. https://doi.org/10.1016/j.jcorpfin.2014.10.016

Dahlke J., Bogner K., Becker M., Schlaile M.P., Pyka A., Ebersberger B. (2021) Crisis-driven innovation and fundamental human needs: A typological framework of rapid-response COVID-19 innovations. Technological Forecasting and Social Change, 169, 1-23. https://doi.org/10.1016/j.techfore.2021.120799

\footnotetext{
${ }^{12} \mathrm{https} / / / \mathrm{rb} . \mathrm{ru} / \mathrm{regions} / \mathrm{kazan} /$, accessed on 19.08.2021.
} 
Davidsson P., Recker J., von Briel F. (2020) External enablement of new venture creation: A framework. Academy of Management Perspectives, 34(3), 311-332. https://doi.org/10.5465/amp.2017.0163

Delgado M., Porter M.E., Stern S. (2010) Clusters and entrepreneurship. Journal of Economic Geography, 10(4), 495-518. DOI:10.2139/ssrn.1689084

Doern R., Williams N., Vorley T. (2019) Special issue on entrepreneurship and crises: Business as usual? An introduction and review of the literature. Entrepreneurship \& Regional Development, 31(5-6), 400-412. https://doi.org/10.1080/08985626.20 18.1541590

Dukhon A.B., Zinkovsky K.V., Obraztsova O.I., Chepurenko A.Yu. (2018) The Impact of Entrepreneurial Education Programs on Small Business Development in Russia: An Empirical Experience in a Regional Context. Educational Studies Moscow, 2, 139-172. DOI: 10.17323/1814-9545-2018-2-139-172 (in Russ.).

Eggers F. (2020) Masters of disasters? Challenges and opportunities for SMEs in times of crisis. Journal of Business Research, 116, 199-208. https://doi.org/10.1016/j.jbusres.2020.05.025

Erikson T. (2002) Entrepreneurial capital: The emerging venture's most important asset and competitive advantage. Journal of Business Venturing, 17(3), 275-290. https://doi.org/10.1016/S0883-9026(00)00062-8

Eriksson R., Rataj M. (2019) The geography of starts-ups in Sweden. The role of human capital, social capital and agglomeration. Entrepreneurship \& Regional Development, 31(9-10), 735-754. https://doi.org/10.1080/08985626.2019.1565420

Fossen F., Sorgner A. (2021) Digitalisation of work and entry into entrepreneurship. Journal of Business Research, 125, 548563. https://doi.org/10.1016/j.jbusres.2019.09.019.

Fritsch M., Aamoucke R. (2013) Regional public research, higher education, and innovative start-ups: An empirical investigation. Small Business Economics, 41(4), 865-885. https://doi.org/10.1007/s11187-013-9510-z

Fritsch M., Wyrwich M. (2018) Regional knowledge, entrepreneurial culture, and innovative start-ups over time and space An empirical investigation. Small Business Economics, 51(2), 337-353. https://doi.org/10.1007/s11187-018-0016-6

Fritsch M., Wyrwich M. (2019) Regional Emergence of Start-Ups in Information Technologies: The Role of Knowledge, Skills and Opportunities. Foresight and STI Governance, 13(2), 62-71. DOI: 10.17323/2500-2597.2019.2.62.71

Goel R.K., Saunoris J.W. (2017) Dynamics of knowledge spillovers from patents to entrepreneurship: Evidence across entrepreneurship types. Contemporary Economic Policy, 35(4), 700-715. https://doi.org/10.1111/coep.12224

Gokhberg L.M., Kuznetsova T.E. (2012) Innovation as the basis of economic growth and strengthening of Russia's position in the global economy. International Organisations Research Journal, 7 (2), 101-117. (In Russ.)

Guerrero M., Urbano D., Fayolle A. (2016) Entrepreneurial activity and regional competitiveness: Evidence from European entrepreneurial universities. The Journal of Technology Transfer, 41(1), 105-131. https://doi.org/10.1007/s10961-014-9377-4

Guriev S., Sonin K. (2008) Economics of the "resource curse". Voprosy Ekonomiki, 4, 61-74. https://doi.org/10.32609/00428736-2008-4-61-74 (in Russ.).

Isenberg D. (2011) The entrepreneurship ecosystem strategy as a new paradigm for economy policy: Principles for cultivating entrepreneurship. Paper presented at the Institute of International and European Affairs, May 12, 2011, Dublin, Ireland.

Kuckertz A., Braendle L., Gaudig A., Hinderer S., Morales Reyes C.A., Prochotta A., Steinbrink K., Berger E.S.C. (2020) Startups in times of crisis - A rapid response to the COVID-19 pandemic. Journal of Business Venturing Insights, 13, 1-13. https:// doi.org/10.1016/j.jbvi.2020.e00169

Kudrin A.L., Mau V.A., Radygin A.D., Sinelnikov-Murylev S.G. (eds.) (2021) Russian economy in 2020. Trends and Prospects, Moscow: Gaidar Institute Publishing (in Russ.).

Lasch F., Robert F., Le Roy F. (2013) Regional determinants of ICT new firm formation. Small Business Economics, 40(3), 671-686. https://doi.org/10.1007/s11187-011-9382-z

Lee S.Y., Florida R., Acs Z. (2004) Creativity and entrepreneurship: A regional analysis of new firm formation. Regional Studies, 38(8), 879-891. https://doi.org/10.1080/0034340042000280910

Lyubimov I.L. (2016) Could the resource course be good for the Russian economy? Russian Journal of Entrepreneurship, 17 (10), 1265-1274. DOI:10.18334/rp.17.10.35292 (In Russ.)

Mason C., Brown R. (2014) Entrepreneurial ecosystems and growth oriented entrepreneurship, Paris: OECD.

Mau V. A., Idrisov G.I., Kouzminov Ya. I., Radygin A. D., Sadovnichiy V.A., Sinelnikov-Murylev S.G. (eds.) (2020) Society and Pandemic: Experience and Lessons from Fighting COVID-19 in Russia, Moscow: RANEPA, HSE, Plekhanov Russian University of Economics, Lomonosov Moscow State University, MGIMO, Russian Foreign Trade Academy, RF Ministry of Economic Development; Finance Research Institute of the RF Finance Ministry, Gaidar Institute for Economic, RF Central Bank; VCIOM; ANO "National Priorities", Sberbank (in Russ.)

Obraztsova O., Chepurenko A. (2020) Policy towards SMEs in the Russian Federation: An update after the pandemic? Public Administration Issues, 3, 71-95 (in Russ.). DOI: 10.17323/1999-5431-2020-0-3-71-95

OECD (2020) Policy Responses to Coronavirus, Paris: OECD.

Perignat E., Katz-Buonincontro J. (2019) STEAM in practice and research: An integrative literature review. Thinking Skills and Creativity, 31, 31-43. https://doi.org/10.1016/j.tsc.2018.10.002

Plummer L.A. (2010) Spatial dependence in entrepreneurship research: Challenges and methods. Organisational Research Methods, 13(1), 146-175. https://doi.org/10.1177\%2F1094428109334199

Qian H., Acs Z.J., Stough R. (2012) Regional systems of entrepreneurship: The nexus of human capital, knowledge and new firm formation. Journal of Economic Geography, 13(4), 559-587. https://doi.org/10.1093/jeg/lbs009 
Ries E. (2011) The lean start-up: How today's entrepreneurs use continuous innovation to create radically successful businesses, New York, Crown Business.

Saxenian A.L. (1996) Regional Advantage: Culture and Competition in Silicon Valley and Route 128, Cambridge, Harvard University Press.

Semenova R., Barinova V., Zemtsov S. (2019) State support of high technologies and innovations in Russia. Innovation, 245 (3), 33-44 (in Russ.).

Shirokova G., Osiyevskyy O., Bogatyreva K. (2016) Exploring the intention-behavior link in student entrepreneurship: Moderating effects of individual and environmental characteristics. European Management Journal, 34(4), 386-399. https:// doi.org/10.1016/j.emj.2015.12.007

Shirokova G., Tsukanova T., Morris M.H. (2018) The moderating role of national culture in the relationship between university entrepreneurship offerings and student start-up activity: An embeddedness perspective. Journal of Small Business Management, 56(1), 103-130. https://doi.org/10.1111/jsbm.12363

Smallbone D., Welter F. (ed.) (2020) Research Agenda for Entrepreneurship Policy, Northampton: Edward Elgar Publishing.

Stuetzer M., Obschonka M., Schmitt-Rodermund E. (2013) Balanced skills among nascent entrepreneurs. Small Business Economics, 41(1), 93-114. https://doi.org/10.1007/s11187-012-9423-2

Sun B., Zhu P., Li W. (2019) Cultural diversity and new firm formation in China. Regional Studies, 53(10), 1371-1384. https:// doi.org/10.1080/00343404.2019.1566700

Verheul I., Wennekers S., Audretsch D., Thurik R. (2002) An eclectic theory of entrepreneurship: Policies, institutions and culture. In: Entrepreneurship: Determinants and policy in a European-US comparison, Heidelberg, Dordrecht, London, New York: Springer, pp. 11-81. https://doi.org/10.1007/0-306-47556-1_2

Williams T.A., Shepherd D.A. (2016) Victim entrepreneurs doing well by doing good: Venture creation and well-being in the aftermath of a resource shock. Journal of Business Venturing, 31(4), 365-387. https://doi.org/10.1016/j.jbusvent.2016.04.002

Wright M., Hmieleski K.M., Siegel D.S., Ensley M.D. (2007) The role of human capital in technological entrepreneurship. Entrepreneurship Theory and Practice, 31(6), 791-806. https://doi.org/10.1111\%2Fj.1540-6520.2007.00202.x

Zbierowski P. (2017) The Aspirations of New Technology-Based Firms in CEE and CIS Countries. Foresight and STI Governance, 11(3), 50-60. DOI: 10.17323/2500-2597.2017.3.50.60

Zemtsov S. (2020) New technologies, potential unemployment and 'nescience economy' during and after the 2020 economic crisis. Regional Science Policy \& Practice, 12(4), 723-743. https://doi.org/10.1111/rsp3.12286

Zemtsov S., Eremkin V., Barinova V. (2015) Factors of attractiveness of the leading Russian Universities: Overview of literature and econometric analysis of the leading universities. Voprosy Ekonomiki, 4, 201-233. DOI: 10.17323/1814-9545-2015-4201-233 (in Russ.).

Zemtsov S.P. (2020) Institutions, Entrepreneurship and Regional Development in Russia. Journal of the New Economic Association, 46(2), 168-180 (in Russian).

Zemtsov S.P., Chepurenko A.Yu., Barinova V.A., Krasnoselskikh A.N. (2020) New entrepreneurship policy in Russia after the 2020 crisis. Voprosy Ekonomiki, 10, 44-67. DOI:10.32609/0042-8736-2020-10-1-24 (in Russian). 